\title{
INFLUENCE OF ORGANIC AND INORGANIC FERTILIZERS ON THE GROWTH, LEAF YIELD, CHLOROPHYLL AND PROTEIN CONTENTS OF STEVIA GROWN IN DIFFERENT SOIL TYPES
}

\author{
S. Khanom, B. K. Saha, M. T. Islam and M. A. H. Chowdhury \\ Department of Agricultural Chemistry, Bangladesh Agricultural University \\ Mymensingh-2002, Bangladesh
}

\begin{abstract}
A pot experiment was conducted in the open net house of the Department of Agricultural Chemistry, Bangladesh Agricultural University, Mymensingh from January to June, 2007, to study the effect of organic and inorganic fertilizers on the growth, leaf yield, chlorophyll and protein contents of Stevia rebaudiana (Bert.). The experiment was laid out in completely randomized design with three replications having 16 treatment combinations. Four types of soil viz., saline, acidic, calcareous and non-calcareous soils were collected from Khulna, Tangail, Natore and Mymensingh districts of Bangladesh, respectively. Two organic (poultry manure and cow dung) and one inorganic fertilizers @ the recommended dose along with a control were used as treatment factor. The experimental results indicated that different soil types significantly influenced all parameters studied. The highest values of all parameters were obtained from the plant grown in noncalcareous soil which was identical with acidic soil for some parameters. Different types of organic and inorganic fertilizer had also significant influence on all plant parameters. In all cases, the highest values were recorded from the plant fertilized with chemical fertilizers. Poultry manure and cow dung also showed identical results with chemical fertilizer in most cases. Interaction effect of different types of soil and fertilizer showed significant variation for most of the parameters studied except chlorophyll and protein contents. Plants grown in noncalcareous soil fertilized with chemical fertilizers exhibited the best performance in most of the cases. The overall results suggested that stevia can be cultivated in noncalcareous and acidic soils fertilized with chemical fertilizers along with poultry manure favoring the productivity of stevia.
\end{abstract}

Key words : Stevia, Soil types, Manures and fertilizers, Chlorophyll, Protein

\section{INTRODUCTION}

There is an increasing tendency towards consuming natural products for a natural life. At the same time our life styles have changed so much over the last 4-5 decades that sweeteners have become integral part of our natural daily diet. Due to sedentary life styles, the incidence of obesity and diabetic conditions are increasing dramatically. In Bangladesh, the number of diabetic people in the age group of 25- 45 is increasing at an alarming pace. Stevia rebaudiana (Bert.) is a perennial shrub of the family Compositae native to certain regions of the South America particularly Paraguay and Brazil where its leaves have long been known to be sweet tasting. Recently, it has been introduced as a 
crop in a number of countries and has become a popular natural source of high-potency sweetener and dietary supplement. Leaves of the stevia plant produce zero-calorie steviosides. The major sweet compound stevioside is a nutritive, high-potency sweetener, and substitute to sucrose, being 300 times sweeter than sucrose (Geuns, 2004). It is a new crop and is gaining very high popularity amongst all type of sweetener users as most ideal substitute for sugar. Bangladesh being an agro-based country could easily cultivate this important plant and can help to meet up sugar demand. Stevioside content actually varies from 4 to $20 \%$ depending on cultivar, soil and other environmental factors (Geuns, 2004). Though some trials have been tried by Bangladesh Rural Advancement Committee (BRAC) and Bangladesh Sugarcane Research Institute (BSRI) at their biotechnology and tissue culture labs for the vegetative propagation of stevia, no detailed report on the agronomy and physiological aspects of this crop were found in Bangladesh. Therefore, this experiment was conducted to study the ideal soil condition and appropriate cultivation technique to obtain better plant growth, higher leaf yield, protein and chlorophyll contents for its large scale production in Bangladesh.

\section{MATERIALS AND METHODS}

To examine the growth, leaf yield, chlorophyll and protein contents of stevia, a pot experiment was conducted at the net house of the Department of Agricultural Chemistry, Bangladesh Agricultural University, Mymensingh from January to June, 2007. Four different soil types namely saline, acidic, calcareous and noncalcareous soils were collected from different districts of Bangladesh viz. Khulna (Koira), Tangail (Madhupur), Natore (Kachi Kata) and Mymensingh (BAU Campus), respectively. The initial surface soils $(0-15 \mathrm{~cm})$ were collected, air dried, ground and sieved through a $5 \mathrm{~mm}$ sieve and then $8.5 \mathrm{~kg}$ soil was poured into each earthen pot. Soil samples were analyzed following the standard methods (Page et al., 1982). The physical and chemical properties of soils have been presented in Table 1.

Table 1. Physical and chemical properties of the experimental soils

\begin{tabular}{l|c|c|c|c}
\hline \multirow{2}{*}{ Soil properties } & \multicolumn{4}{c}{ Different soil types } \\
\cline { 2 - 5 } & Saline & Acidic & Calcareous & Non-calcareous \\
\hline Textural class & Silt loam & Clay loam & Clay loam & Silt loam \\
$\mathrm{pH}$ & 7.8 & 4.7 & 6.9 & 6.5 \\
Total N $(\%)$ & 0.17 & 0.12 & 0.22 & 0.15 \\
Available P ( $\mu \mathrm{g} \mathrm{g}^{-1}$ soil) & 5.12 & 5.41 & 17.94 & 14.31 \\
Exchangeable K (cmol kg-1 ${ }^{\text {soil) }}$ & 0.14 & 0.18 & 0.40 & 0.16 \\
Available S $\left(\mu \mathrm{g} \mathrm{g}^{-1}\right.$ soil) & 30.4 & 4.15 & 15.94 & 10.66 \\
\hline
\end{tabular}

Two organic (poultry manure and cow dung) and one inorganic fertilizer along with a control were used as treatment factor in this experiment. Since stevia has been newly introduced in Bangladesh, no fertilizer recommendation exists for this herb. Therefore, urea, triple superphosphate, muriate of potash, gypsum, cow dung and poultry manure 
were applied according to the fertilizer recommendation for Indian spinach (BARC, 2005). One-third amount of urea and full dose of other fertilizers were applied one day before transplanting. The rest part of urea was applied at 20 and 40 days after transplanting (DAT). Well-decomposed cow dung and poultry manure was mixed thoroughly with the soil of the respective pot 15 days before transplanting. Stem cuttings were collected from Plant Biotechnology Lab, BRAC, Joydebpur, Gazipur. One seedling was transplanted in each pot following completely randomized design with three replications. Intercultural operations were done to ensure normal crop growth and when necessary. Adequate soil moisture content was maintained by addition of distilled water regularly. The leaf area of the plant was measured by a leaf area meter (Systronics-114). The crop was harvested at $60 \mathrm{DAT}$ and the leaves were taken for chemical analyses. The chlorophyll content was measured following the method of Arnon (1949). Nitrogen content was determined following micro kjeldahl method as described by Jackson (1973) and protein content was calculated multiplying the total $\mathrm{N}$ content by 5.85 . Analysis of variance was done with the help of computer package MSTAT developed by Russel (1986) and the mean differences of the treatments were adjudged by LSD test.

\section{RESULTS AND DISCUSSION}

\section{Plant height}

Different types of soil influenced significantly the plant height of stevia at 15, 30, 45 and 60 DAT. Plant height increased rapidly from 0 to 60 DAT in all soils and the increase rate was almost similar. The tallest plant $(69.42 \mathrm{~cm})$ was found in noncalcareous soil at 60 DAT which was identical with the plant grown in saline soil at same DAT and significantly different from the plant grown in other soils. The shortest plant $(17.42 \mathrm{~cm})$ was observed in saline soil at 0 DAT (Fig. 1A). It is evident that plant height was significantly affected due to various fertilizers application at different DAT except at 0 DAT. Application of different fertilizers gradually increased plant height with the increase in DAT and reached its maximum value at 60 DAT. The tallest plant $(67.83 \mathrm{~cm})$ was identified from the pot treated with chemical fertilizer at 60 DAT which was identical with the plant height obtained from cow dung and poultry manure treated plant at the same DAT and the dwarf plant $(16.3 \mathrm{~cm})$ was noticed in control treatment at 0 DAT (Fig. 1B). Thus the finding was in agreement with that of Ojeniyi et al. (2007) who reported that application of $\mathrm{N}, \mathrm{P}, \mathrm{K}$ and animal manure increased the plant height of tomato as compared to control. A similar finding was reported by Akande et al., (2006) who observed that cow dung manure significantly increased the plant height of maize, okra and cowpea. Interaction effect of different types of soil and fertilizer showed significant variation with respect to plant height at different DAT except at 0 DAT. The tallest plant $(74.33 \mathrm{~cm})$ was observed in noncalcareous soil treated with chemical fertilizer at 60 DAT which was identical with the plant grown in noncalcareous and acidic soils fertilized with poultry manure and cow dung at the same DAT. The shortest plant (14 $\mathrm{cm}$ ) was identified in saline soil which was not fertilized by any fertilizer at 0 DAT (Table 2). Silva et al. (2005) obtained the higher crop growth and yield of maize by combining organic manures and chemical fertilizers. 

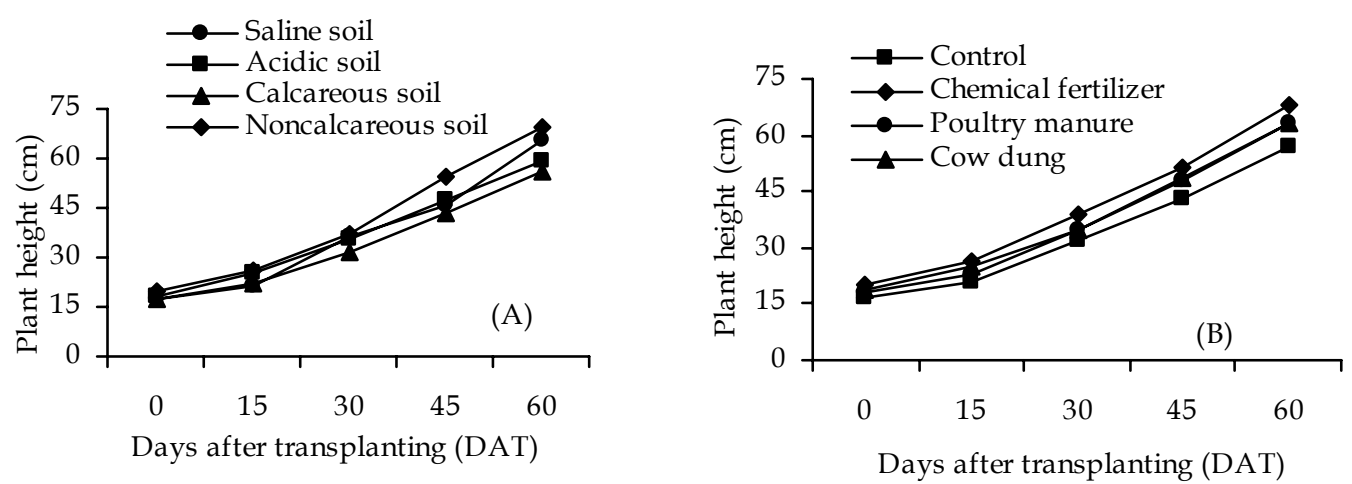

Fig. 1. Effect of different types of soil (A) and fertilizer (B) on plant height of stevia at different days after transplanting. Bars indicate LSD value at $5 \%$ level of significance

\section{Number of branches}

The number of branches was significantly influenced by various types of soil at different DAT. Branch increased slowly up to 30 DAT and then a rapid and sharp increase was found from 30 to 60 DAT in all soils except calcareous soil. Maximum number of branch (42.08) was counted from the plant grown in noncalcareous soil at 60 DAT and it was minimum (1.67) in saline and calcareous soils at 0 DAT (Fig. 2A). Significant variation was observed in number of branch due to the application of different fertilizers at different DAT. Number of branch increased gradually up to 30 DAT in all fertilizer treatments. A tremendous increase in branch number was found in chemical fertilizer treated plant from 30 to 60 DAT where as the increase rate was medium in cow dung and poultry manure treated plants and slower at control treated plant. Maximum number of branch (51.25) was obtained from plant fertilized with chemical fertilizer at 60 DAT and minimum (1.58) was counted from control treatment at 0 DAT (Fig. 2B). This finding was in agreement with that of Ojeniyi et al. (2007) who observed that application of N, P, K and animal manure increased the number of branch of tomato as compared to control. Number of branch differed significantly by the interaction effect of different types of soil and fertilizer at different DAT. Maximum number of branch (63.67) was recorded from the chemical fertilizer treated plant grown in acidic soil at 60 DAT which was identical with the plant grown in noncalcareous soil fertilized with cow dung. Minimum number of branch (11.67) was counted from the plant grown in saline soil fertilized with chemical fertilizers (Table 2).

\section{Number of leaf}

Significant variation was found in the number of stevia leaves grown in various soil types at 15, 30, 45 and 60 DAT. Leaves increased rapidly and sharply with the advanced growth stages of the plant in all soils except calcareous soil. The increase rate was very high in noncalcareous soil, medium in saline and acidic soils and very much lower in calcareous soil. The highest number of leaves (292.08) was counted from the plant grown in noncalcareous soil at 60 DAT which was significantly different from plants grown in 
other soils and the lowest value (17.08) was recorded from saline soil at 0 DAT (Fig. 3A). Number of leaves differed significantly due to fertilizer application at different DAT. Initially the number of leaves was almost similar in each treatment then it increased slowly up to 30 DAT in all treatments. A rapid and tremendous increase in leaves number was observed in chemical fertilizer treated plant from 30 to 60 DAT where as the increase rate was not so sharp in cowdung and poultry manure treated plant and very much slower in control treated plant. The highest number of leaf (278.75) was counted from the plant treated with chemical fertilizer at 60 DAT which was significantly different from the plants treated with other fertilizers including control. The lowest number of leaf (14.33) was counted from the control treatment at 0 DAT (Fig. 3B). Different types of soil and fertilizer interacted significantly to bring variation in the number of leaves at different DAT. The highest number of leaves (432.0) was recorded from the chemical fertilizer treated plant grown in noncalcareous soil at 60 DAT and the lowest number (24.0) was counted from the unfertilized plant grown in calcareous soil (Table 5). Ojeniyi et al. (2007) found that application of N, P, K and animal manure increased the number of leaf in tomato as compared to control.

Table 2. Interaction effect of different types of soil and fertilizer on plant height and branch number of stevia at different days after planting

\begin{tabular}{|c|c|c|c|c|c|c|c|c|c|c|c|}
\hline \multirow{2}{*}{\multicolumn{2}{|c|}{$\begin{array}{c}\text { Interaction } \\
S \times T\end{array}$}} & \multicolumn{5}{|c|}{ Plant height $(\mathrm{cm})$} & \multicolumn{5}{|c|}{ Branch plant ${ }^{-1}$ (No.) } \\
\hline & & \multirow{2}{*}{$\begin{array}{c}0 \\
14.00\end{array}$} & \multirow{2}{*}{$\begin{array}{c}15 \\
19.00\end{array}$} & \multirow{2}{*}{$\begin{array}{c}30 \\
32.33\end{array}$} & \multirow{2}{*}{\begin{tabular}{|c|}
45 \\
42.17
\end{tabular}} & \multirow{2}{*}{$\begin{array}{c}60 \\
60.67\end{array}$} & \multirow{2}{*}{$\begin{array}{c}0 \\
1.00\end{array}$} & \multirow{2}{*}{$\begin{array}{c}15 \\
1.67\end{array}$} & \multirow{2}{*}{$\frac{30}{3.00}$} & \multirow{2}{*}{$\begin{array}{c}45 \\
7.00\end{array}$} & \multirow{2}{*}{$\frac{60}{13.67}$} \\
\hline $\mathrm{S}_{1}$ & $\mathrm{~T}_{1}$ & & & & & & & & & & \\
\hline $\mathrm{S}_{1}$ & $\mathrm{~T}_{2}$ & 17.33 & 20.00 & 33.00 & 43.00 & 63.67 & 2.00 & 2.67 & 4.00 & 6.67 & 11.67 \\
\hline $\mathrm{S}_{1}$ & $\mathrm{~T}_{3}$ & 18.00 & 22.67 & 36.67 & 46.00 & 68.00 & 2.00 & 2.67 & 3.33 & 21.00 & 44.33 \\
\hline $\mathrm{S}_{1}$ & $\mathrm{~T}_{4}$ & 19.33 & 23.67 & 42.33 & 50.50 & 68.33 & 1.67 & 2.00 & 3.00 & 15.67 & 32.33 \\
\hline $\mathrm{S}_{2}$ & $\mathrm{~T}_{1}$ & 21.33 & 27.00 & 41.33 & 51.00 & 63.67 & 1.67 & 2.33 & 3.67 & 40.00 & 18.33 \\
\hline $\mathrm{S}_{2}$ & $\mathrm{~T}_{2}$ & 19.33 & 25.67 & 35.67 & 50.00 & 61.33 & 2.00 & 2.67 & 6.33 & 10.67 & 21.33 \\
\hline $\mathrm{S}_{2}$ & $\mathrm{~T}_{3}$ & 18.33 & 26.67 & 34.00 & 45.33 & 59.33 & 2.00 & 2.67 & 5.00 & 11.67 & 18.67 \\
\hline $\mathrm{S}_{2}$ & $\mathrm{~T}_{4}$ & 15.00 & 21.33 & 31.33 & 44.00 & 53.67 & 1.67 & 2.33 & 4.00 & 9.67 & 63.67 \\
\hline $\mathrm{S}_{3}$ & $\mathrm{~T}_{1}$ & 17.00 & 18.33 & 28.67 & 38.33 & 52.00 & 1.67 & 2.00 & 3.00 & 13.00 & 16.33 \\
\hline $\mathrm{S}_{3}$ & $\mathrm{~T}_{2}$ & 16.33 & 20.67 & 32.00 & 44.00 & 55.00 & 1.33 & 2.33 & 4.00 & 24.00 & 20.67 \\
\hline $\mathrm{S}_{3}$ & $\mathrm{~T}_{3}$ & 17.33 & 23.33 & 31.00 & 44.33 & 53.67 & 1.67 & 1.67 & 3.00 & 23.00 & 17.67 \\
\hline $\mathrm{S}_{3}$ & $\mathrm{~T}_{4}$ & 19.33 & 25.00 & 33.33 & 47.00 & 65.00 & 2.00 & 3.33 & 7.00 & 30.67 & 50.00 \\
\hline $\mathrm{S}_{4}$ & $\mathrm{~T}_{1}$ & 18.33 & 23.33 & 35.00 & 47.67 & 60.67 & 2.00 & 2.33 & 4.33 & 14.67 & 18.00 \\
\hline $\mathrm{S}_{4}$ & $\mathrm{~T}_{2}$ & 19.67 & 24.33 & 38.33 & 55.67 & 71.67 & 2.00 & 2.67 & 4.33 & 23.33 & 36.00 \\
\hline $\mathrm{S}_{4}$ & $\mathrm{~T}_{3}$ & 20.33 & 28.00 & 37.33 & 57.67 & 71.00 & 1.67 & 3.00 & 7.33 & 25.33 & 55.33 \\
\hline $\mathrm{S}_{4}$ & $\mathrm{~T}_{4}$ & 21.67 & 29.33 & 39.33 & 58.33 & 74.33 & 2.67 & 6.00 & 10.33 & 29.33 & 59.00 \\
\hline \multicolumn{2}{|c|}{ LSD $(0.05)$} & 5.62 & 6.07 & 7.04 & 9.13 & 10.09 & 0.67 & 1.66 & 3.20 & 8.17 & 9.60 \\
\hline \multicolumn{2}{|c|}{ CV (\%) } & 18.41 & 15.45 & 12.06 & 11.49 & 9.69 & 22.52 & 37.80 & 40.72 & 25.72 & 18.60 \\
\hline
\end{tabular}

Legend : $S_{1}=$ Saline soil, $S_{2}=$ Acidic soil, $S_{3}=$ Calcareous soil, $S_{4}=$ Noncalcareous soil, $T_{1}=$ Control, $\mathrm{T}_{2}=$ Chemical fertilizer, $\mathrm{T}_{3}=$ Poultry manure, $\mathrm{T}_{4}=$ Cow dung 

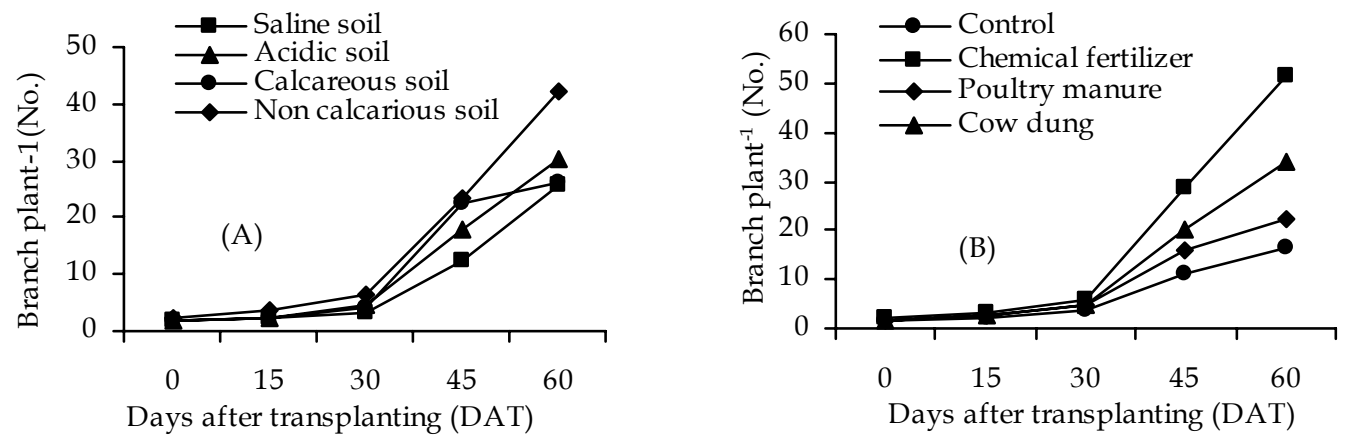

Fig. 2. Effect of different types of soil (A) and fertilizer (B) on branch number of stevia at different days after transplanting. Bars indicate LSD value at $5 \%$ level of significance
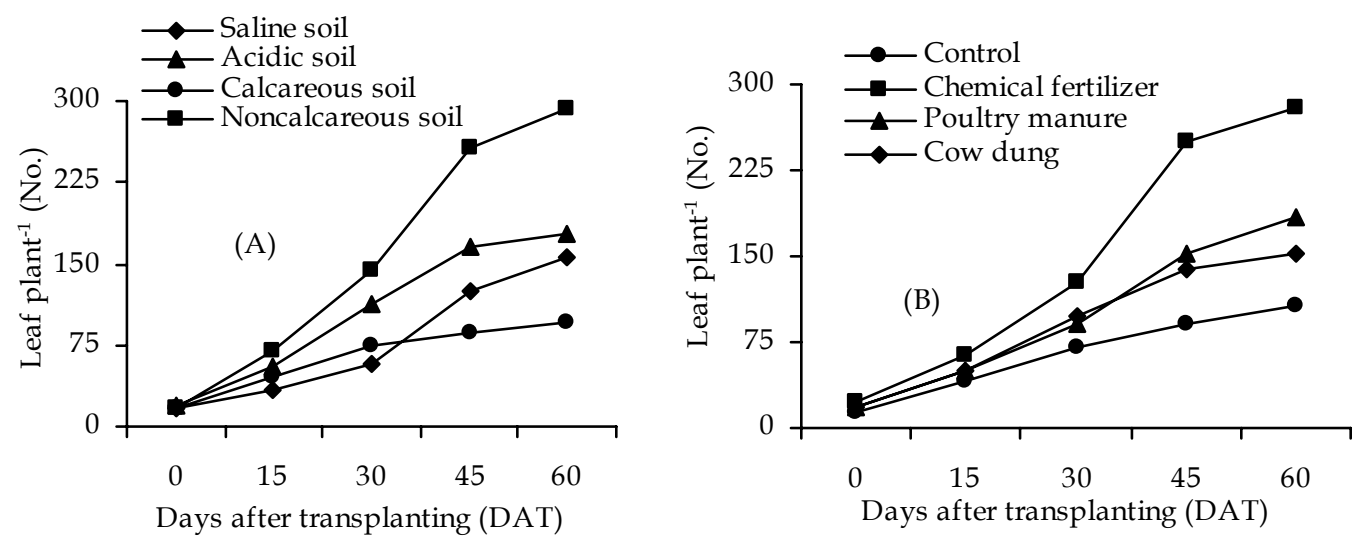

Fig. 3. Effect of different types of soil (A) and fertilizer (B) on number of leaves of stevia at different days after transplanting. Bars indicate LSD value at $5 \%$ level of significance

\section{Leaf area}

The leaf area plant ${ }^{-1}$ of stevia was significantly influenced by different soil types. Maximum leaf area $\left(1401 \mathrm{~cm}^{2}\right)$ was measured from the plant grown in noncalcareous soil and it was minimum $\left(754 \mathrm{~cm}^{2}\right)$ in calcareous soil (Table 3). Significant variation was observed in leaf area due to the application of different fertilizers. Maximum leaf area $\left(1427 \mathrm{~cm}^{2}\right)$ was obtained from the plant treated with chemical fertilizers and minimum $\left(667 \mathrm{~cm}^{2}\right)$ was recorded from the unfertilized plant (Table 4). Akande et al. (2006) observed that the application of cow dung significantly increased the leaf area of maize and okra compared to control. Leaf area was also affected significantly by the interaction effect of different types of soil and fertilizer. The highest leaf area $\left(1901 \mathrm{~cm}^{2}\right)$ was recorded from the chemical fertilizers treated plant grown in noncalcareous soil and the lowest area $\left(443 \mathrm{~cm}^{2}\right)$ was measured from the unfertilized plant grown in calcareous soil (Table 5). Ojeniyi et al. (2007) reported that application of N, P, K fertilizers and animal manure increased the leaf area of tomato as compared to control. 


\section{Leaf length}

Different types of soil significantly influenced the leaf length of stevia. The longest leaf $(6.34 \mathrm{~cm})$ was recorded from the plant grown in noncalcareous soil and the shortest (5.54 $\mathrm{cm}$ ) was measured from calcareous soil (Table 3). Leaf length was significantly affected due to the application of different fertilizers. The longest $(6.81 \mathrm{~cm})$ and shortest $(4.31 \mathrm{~cm})$ leaves were identified from the chemically fertilized and unfertilized plants, respectively (Table 4). Leaf length was not significantly influenced by the interaction effect of different types of soil and fertilizer. The longest leaf $(7.6 \mathrm{~cm})$ was recorded from the plants grown in noncalcareous soil fertilized with cow dung and the shortest leaf $(4.03 \mathrm{~cm})$ was identified from the unfertilized plant grown in calcareous soil (Table 5).

\section{Leaf breadth}

The results revealed that different types of soil significantly influenced the leaf breadth of stevia. The widest leaf $(2.72 \mathrm{~cm})$ was measured from the plant grown in noncalcareous soil which was identical with acid soil. The narrowest leaf $(2.21 \mathrm{~cm})$ was recorded from plant grown in saline soil (Table 3). Significant variation in leaf breadth was found due to the application of different fertilizers. The widest leaf $(2.82 \mathrm{~cm})$ was measured from the plant treated with chemical fertilizers and the narrowest $(2.24 \mathrm{~cm})$ was recorded from poultry manure treated plant (Table 4 ). Different types of soil and fertilizer interacted significantly to produce variation in leaf breadth. The widest leaf $(3.93 \mathrm{~cm})$ was recorded from the cow dung treated plant grown in noncalcareous soil and the narrowest leaf (1.43 $\mathrm{cm}$ ) was identified from unfertilized plant grown in calcareous soil (Table 5).

Table 3. Effect of different types of soil on leaf area, leaf length and breadth, total chlorophyll and protein contents of stevia

\begin{tabular}{l|c|c|c|c|c}
\hline $\begin{array}{c}\text { Different } \\
\text { soil types }\end{array}$ & $\begin{array}{c}\text { Leaf area } \\
\text { plant }^{-1}\left(\mathrm{~cm}^{2}\right)\end{array}$ & $\begin{array}{c}\text { Leaf length } \\
(\mathrm{cm})\end{array}$ & $\begin{array}{c}\text { Leaf breadth } \\
(\mathrm{cm})\end{array}$ & $\begin{array}{c}\text { Total chlorophyll } \\
\text { content }\left(\mathrm{mg} \mathrm{g}^{-1} \mathrm{fw}\right)\end{array}$ & $\begin{array}{c}\text { Protein } \\
\text { content }(\%)\end{array}$ \\
\hline Saline soil & 857 & 5.86 & 2.21 & 2.54 & 5.70 \\
Acidic soil & 1133 & 6.04 & 2.43 & 2.71 & 5.31 \\
Calcareous soil & 754 & 5.54 & 2.37 & 2.06 & 5.40 \\
Noncalcareous soil & 1401 & 6.34 & 2.72 & 3.22 & 6.29 \\
\hline LSD (0.05) & 21.45 & 0.28 & 0.28 & 0.29 & 0.60 \\
\hline CV (\%) & 2.47 & 11.19 & 14.11 & 13.51 & 12.78 \\
\hline
\end{tabular}

\section{Total chlorophyll content}

Total chlorophyll content of stevia leaves was significantly influenced by different types of soil. Maximum chlorophyll content $\left(3.22 \mathrm{mg} \mathrm{g}^{-1} \mathrm{fw}\right)$ was determined from the plant grown in noncalcareous soil and it was minimum $\left(2.06 \mathrm{mg} \mathrm{g}^{-1} \mathrm{fw}\right)$ in saline and calcareous soils (Table 3). Significant variation was observed in chlorophyll content due to the application of different fertilizers. Maximum chlorophyll content $\left(3.26 \mathrm{mg} \mathrm{g}^{-1} \mathrm{fw}\right)$ was obtained from the plant treated with chemical fertilizer and minimum $\left(1.82 \mathrm{mg} \mathrm{g}^{-1}\right.$ $\mathrm{fw}$ ) was measured from unfertilized plant (Table 4). Chlorophyll content was not 
significantly influenced by the interaction effect of different types of soil and fertilizer. The highest chlorophyll content $\left(3.93 \mathrm{mg} \mathrm{g}^{-1}\right)$ was recorded from the cow dung treated plant grown in noncalcareous soil and the lowest content $\left(1.43 \mathrm{mg} \mathrm{g}^{-1}\right)$ was recorded from unfertilized plant grown in calcareous soil (Table 5).

Table 4. Effect of different types of fertilizer on leaf area, leaf length and breadth, total chlorophyll and protein contents of stevia

\begin{tabular}{l|c|c|c|c|c}
\hline $\begin{array}{c}\text { Different types of } \\
\text { fertilizer }\end{array}$ & $\begin{array}{c}\text { Leaf area } \\
\text { plant }^{-1}\left(\mathrm{~cm}^{2}\right)\end{array}$ & $\begin{array}{c}\text { Leaf length } \\
(\mathrm{cm})\end{array}$ & $\begin{array}{c}\text { Leaf breadth } \\
(\mathrm{cm})\end{array}$ & $\begin{array}{c}\text { Total chlorophyll } \\
\text { content }\left(\mathrm{mg} \mathrm{g}^{-1} \mathrm{fw}\right)\end{array}$ & $\begin{array}{c}\text { Protein } \\
\text { content }(\%)\end{array}$ \\
\hline Control & 667 & 4.31 & 2.28 & 1.82 & 4.13 \\
Chemical fertilizer & 1427 & 6.81 & 2.82 & 3.26 & 7.79 \\
Poultry manure & 1113 & 6.03 & 2.24 & 2.76 & 5.51 \\
Cow dung & 937 & 6.64 & 2.38 & 2.69 & 5.27 \\
\hline LSD $(0.05)$ & 21.30 & 0.55 & 0.28 & 0.29 & 0.60 \\
\hline CV $(\%)$ & 9.47 & 11.19 & 14.11 & 13.51 & 12.78 \\
\hline
\end{tabular}

Table 5. Interaction effect of different types of soil and fertilizer on leaf number, leaf area, leaf length and breadth, chlorophyll and protein contents of stevia

\begin{tabular}{|c|c|c|c|c|c|c|c|c|c|c|c|}
\hline \multirow{2}{*}{\multicolumn{2}{|c|}{$\begin{array}{c}\text { Interaction } \\
\qquad \times \mathrm{T}\end{array}$}} & \multicolumn{5}{|c|}{ Leaf plant ${ }^{-1}$ (No.) at different DAT } & \multirow{2}{*}{\begin{tabular}{|c|} 
Leaf area \\
plant $^{-1}$ \\
$\left(\mathrm{~cm}^{2}\right)$
\end{tabular}} & \multirow{2}{*}{$\begin{array}{c}\text { Leaf } \\
\text { length } \\
(\mathrm{cm})\end{array}$} & \multirow{2}{*}{$\begin{array}{l}\text { Leaf } \\
\text { breadth } \\
(\mathrm{cm})\end{array}$} & \multirow{2}{*}{$\begin{array}{c}\text { Total chlorophyll } \\
\text { content } \\
\left(\mathrm{mg} \mathrm{g}^{-1} \mathrm{fw}\right)\end{array}$} & \multirow{2}{*}{$\begin{array}{c}\text { Protein } \\
\text { content } \\
(\%)\end{array}$} \\
\hline & & 0 & 15 & 30 & 45 & 60 & & & & & \\
\hline $\mathrm{S}_{1}$ & $\mathrm{~T}_{1}$ & 14.00 & 25.00 & 42.33 & 77.67 & 80.33 & 654 & 4.13 & 1.79 & 1.79 & 3.98 \\
\hline $\mathrm{S}_{1}$ & $\mathrm{~T}_{2}$ & 14.67 & 29.33 & 54.00 & 82.33 & 115.00 & 871 & 5.73 & 2.42 & 2.42 & 5.98 \\
\hline$S_{1}$ & $\mathrm{~T}_{3}$ & 17.00 & 32.00 & 57.00 & 98.00 & 150.33 & 773 & 6.47 & 2.66 & 2.66 & 5.12 \\
\hline $\mathrm{S}_{1}$ & $\mathrm{~T}_{4}$ & 22.67 & 46.67 & 76.33 & 238.33 & 277.33 & 1129 & 7.10 & 3.29 & 3.29 & 7.73 \\
\hline $\mathrm{S}_{2}$ & $\mathrm{~T}_{1}$ & 13.67 & 40.67 & 74.67 & 71.67 & 95.67 & 719 & 4.50 & 1.91 & 1.91 & 4.25 \\
\hline $\mathrm{S}_{2}$ & $\mathrm{~T}_{2}$ & 20.33 & 56.33 & 110.00 & 197.00 & 226.67 & 1164 & 5.93 & 2.86 & 2.86 & 4.67 \\
\hline $\mathrm{S}_{2}$ & $\mathrm{~T}_{3}$ & 21.33 & 52.67 & 116.33 & 171.00 & 136.67 & 985 & 6.27 & 2.66 & 2.66 & 4.98 \\
\hline $\mathrm{S}_{2}$ & $\mathrm{~T}_{4}$ & 23.67 & 72.33 & 148.00 & 221.33 & 252.33 & 1663 & 7.47 & 3.40 & 3.40 & 7.34 \\
\hline $\mathrm{S}_{3}$ & $\mathrm{~T}_{1}$ & 13.33 & 37.33 & 56.00 & 60.00 & 63.67 & 443 & 4.03 & 1.43 & 1.43 & 3.85 \\
\hline $\mathrm{S}_{3}$ & $\mathrm{~T}_{2}$ & 17.33 & 47.67 & 60.67 & 64.00 & 86.00 & 775 & 5.63 & 2.12 & 2.12 & 5.52 \\
\hline $\mathrm{S}_{3}$ & $\mathrm{~T}_{3}$ & 17.33 & 41.00 & 64.67 & 84.67 & 78.00 & 783 & 6.23 & 2.28 & 2.28 & 5.44 \\
\hline $\mathrm{S}_{3}$ & $\mathrm{~T}_{4}$ & 24.00 & 53.33 & 119.33 & 133.67 & 153.33 & 1017 & 6.27 & 2.41 & 2.41 & 6.80 \\
\hline $\mathrm{S}_{4}$ & $\mathrm{~T}_{1}$ & 16.33 & 61.33 & 113.00 & 157.67 & 183.33 & 851 & 4.57 & 2.14 & 2.14 & 4.44 \\
\hline $\mathrm{S}_{4}$ & $\mathrm{~T}_{2}$ & 18.00 & 70.00 & 140.00 & 264.67 & 306.00 & 1643 & 6.80 & 3.64 & 3.64 & 5.87 \\
\hline $\mathrm{S}_{4}$ & $\mathrm{~T}_{3}$ & 18.33 & 70.00 & 152.33 & 201.00 & 247.00 & 1207 & 7.60 & 3.18 & 3.18 & 5.54 \\
\hline $\mathrm{S}_{4}$ & $\mathrm{~T}_{4}$ & 18.67 & 78.67 & 168.00 & 403.33 & 432.00 & 1901 & 6.40 & 3.93 & 3.93 & 9.29 \\
\hline \multicolumn{2}{|c|}{ LSD (0.05) } & 6.19 & 9.53 & 19.03 & 26.67 & 22.63 & 42.61 & 1.10 & 0.57 & 0.59 & 1.20 \\
\hline \multicolumn{2}{|c|}{ CV (\%) } & 20.50 & 11.26 & 11.79 & 10.15 & 7.55 & 2.47 & 11.19 & 13.51 & 14.11 & 12.78 \\
\hline
\end{tabular}

Legend: $\mathrm{S}_{1}=$ Saline soil, $\mathrm{S}_{2}=$ Acidic soil, $\mathrm{S}_{3}=$ Calcareous soil, $\mathrm{S}_{4}=$ Noncalcareous soil, $\mathrm{T}_{1}=$ Control, $\mathrm{T}_{2}=$ Chemical fertilizer, $\mathrm{T}_{3}=$ Poultry manure, $\mathrm{T}_{4}=$ Cow dung. 


\section{Protein content}

The results indicated that different types of soil significantly influenced the protein content of stevia leaf. The highest protein content $(6.29 \%)$ was recorded from the plant grown in noncalcareous soil which was identical with saline soil. The lowest protein content $(5.31 \%)$ was obtained from the plant grown in acidic soil (Table 3). Protein content was affected significantly due to the application of different fertilizers. The highest $(7.79 \%)$ and the lowest $(4.13 \%)$ protein contents were recorded from chemical fertilizer and control treated plant, respectively (Table 4). Pettersson and Wistinghausen (1979) also found a significant difference in protein content of potatoes fertilized organically and chemically. Different types of soil and fertilizer did not interact significantly on protein content. The highest protein content $(9.29 \%)$ was recorded from the cow dung treated plant grown in noncalcareous soil and the lowest content $(3.85 \%)$ was obtained from unfertilized plant grown in calcareous soil (Table 5).

\section{REFERENCES}

Akande, M. O., Oluwatoyinbo, F. I., Kayode, C. O. and Olowokere, F. A. 2006. Response of maize (Zea mays) and okra (Abelmoschus esculentus) intercrop relayed with cowpea (Vigna unguiculata) to different levels of cow dung amended phosphate rock. World J. Agril. Sci. 2(1): 119

Arnon, D. I. 1949. Copper enzymes in isolated chloroplasts polyphenoloxydase in beta vulgaris. Pl. Physiol. 24: 4-5.

BARC (Bangladesh Agricultural Research Council). 2005. Fertilizer Recommendation Guide, Farmgate, Dhaka- 1215.

Geuns, J. M. 2004. The safety of stevioside. Laboratory of Functional Biology. KULeuven, Euprint ed., Parkbosstraat 3, 3001 Heverlee, Belgium. pp: 85-127.

Jackson, M. L. 1973. Soil Chemical Analysis. Prentice Hall of India Pvt. Ltd. New Delhi, India. pp. 41-196.

Ojeniyi, S.O., Awodun, M. A. and Odedina, S. A. 2007. Effect of animal manure amended spent grain and cocoa husk on nutrient status, growth and yield of tomato. MiddleEast J. Sci. Res. 2(1): 33-36.

Page, A. L., R. H. Miller and D. R. Keeney. 1982. Methods of soil analysis. Part-II. $2^{\text {nd }}$ edn. Amer. Soc. Agron. Inc. Medison, Washington, USA.

Pettersson, B. D. and Wistinghausen, E. V. 1979. Effects of organic vs inorganic fertilizers on soils and crops. Miscellaneous Publication \# 1. Woods End Agricultural Institute Temple, Maine.

Russel, D. F. 1986. M-STAT Director. Crop and Soil Science Department. Michigan State University, USA.

Silva, G. E., Cavalcante, A. H. A., Claudio, C. A., Letícia, A. F. F., Gilson, T., Mirian, H. T., Wilson, E. F. and Roberto, B. B. 2006. Investigation of the tolerability of oral stevioside in Brazilian hyperlipidemic patients. Brazilian Arch. Biol. \& Techno. 49(4): 583-587. 